\title{
A Study on the Effects of Family and Delinquent Peers on Juvenile Delinquency in Turkey
}

\author{
Tülin Günşen İçli, Sevgi Çoban \\ Department of Sociology, Hacettepe University, Ankara, Turkey \\ Email: \{ticli, scoban\}@hacettepe.edu.tr
}

Received January $18^{\text {th }}, 2012$; revised February $20^{\text {th }}, 2012$; accepted February $29^{\text {th }}, 2012$

\begin{abstract}
The aim of this article is to explore the effects of peers and family on juvenile delinquency. Open-ended and multiple choice questionnaires were applied to 1526 juveniles in two cities of Turkey; Ankara and Istanbul. Consistent with the literature findings showed that the family has an indirect and partial effect on juvenile's tendency to commit crime because they cannot provide organized social networks, role models, and social controls for their children. On the other hand, by developing a differential association with the juvenile, by which violence and criminal acts are learned, legitimated, supported or encouraged; the peer network has a direct and an incredible influence to initiate the juvenile into crime.
\end{abstract}

Keywords: Juvenile Delinquency; Turkey; Social Learning Theory; Differential Association

\section{Theoretical Framework}

Social learning theory is one of the theories that are referred to explain criminal behavior, whose origins rooted in Gabriel Tarde's theory of imitation. This theory implies that individuals learn certain behavioral patterns by imitating the others' behaviors.

Albert Bandura expands this perspective in a social context and believes that people learn behavior through observing others' behaviors. Consequently, many modes of behavior are learned by observation of other behavior models; and in this way the individual has the knowledge of the ways of displaying subsequent behaviors and thus this codified knowledge directs individual in his/her subsequent behaviors (Bandura, 1977). People's environment or surroundings cause them to behave in certain ways with their power to reinforce or discriminate, and thus environment, individual, and behavior are interrelated (Ormrod, 1999: p. 2).

Social learning theories are based on the assumption that behavior is learned through some certain processes as observation, imitation and behavior modeling (Ormrod, 1999: 1). Within this context, they stress that primary groups and intimate/admiring people are the key factors which compromise the individual's major source of reinforcements (Vito et al., 2007: p. 177). In this way social learning theories highlight both the individual and the social sources of behavior. So, the studies in the field of criminal behavior are more likely to analyze the environment where the crime is learned and criminal behavior than the criminals.

Differential Association Theory, developed by Edwin Sutherland in 1947, is one of the most prominent interactionist theories of deviance. And those social learning theories, which are basically based on Sutherland's Differential Association Theory, broaden the framework of classical symbolic interactionist paradigm, and presume that criminal behavior is learnt within the interaction process with peer groups (Piquero et al., 2005: p. 252). This theory explains criminal behavior with respect to definitions for law-breaking and these definitions refer to the meanings derived from individuals' experiences, forms of apprehension, attitudes, values, and habitual ways of viewing the world (Payne \& Salotti 2007: p. 556). Definitions become favorable or unfavorable to law breaking according to the weight granted definitions made by individuals. Weights are assigned to individuals' definitions in their associations with others, and these associations vary in frequency, duration, priority, and intensity. The earlier people are exposed to criminal norms of conduct 1), the more often they are exposed to them; 2), the longer those exposures last; 3 ), and the more strongly they are attached to those who supply them with the definitions favorable to law violation; 4), the more likely they are to commit criminal acts in case of having enough chance (Cullen \& Agnew, 2003: p. 125).

Within this context it can be stated that differential association is a group interaction process through which the individual gets positive or negative response about the behavior he/she displays. (Payne \& Salotti, 2007: p. 556). In other words, differential association represents groups which make a consensus on definitions favorable to deviance (norm violations) and form a subculture deviant of social norms. And in deviating from the social norms, the individuals who get involved in these groups turn into crime (Sutherland \& Cressey, 1960: p. 132) since as for this theory, criminality is learned through social interaction with others, as well as through impersonal communication.

In addition to this, Sutherland's theory asserts that criminality is the result of conflicting cultural norms. The fact that people from high and low classes have different cultural and operant codes, does not mean that while high class neighborhoods are organized and low class neighborhoods are disorganized or pathological; but rather people from both classes are just different within their own integrity. However, it is proper to state that high crime rates are generally resulted from these conflicts in a given society. Thus, the concept of differential social organization allows us to adequately account for the associations that people have without reference to individual differences. Those mentioned differential associations are thus observable 
among local organizations which are organized in accordance with the individual's social class, his/her family, religion, and race (Matsueda \& Heimer, 1987: p. 827). This fact, in turn, leads to the idea that beliefs and reactions towards crime, differ according to the quality of a given group in modern societies. Although by focusing on the cultural aspects of crime, Sutherland's theory offers an explanation to white collar crimes, street gangs, mafia or juvenile delinquency; it is critized by Burgess and Akers (1966) for not being empirically operational. For instance the definition of and the measuring techniques to be used for these differential associations are not explicitly clarified. Additionally, the assumption that learning criminal behavior embraces all of the mechanisms that are involved in any other learning process, is criticized for not explaining essentially how behavior is learned since it does not explicate those mechanisms mentioned.

According to Burgess and Akers (1966), Sutherland's differential association theory, as being a social theory of crime, says nothing about the mechanisms by which "definitions favorable" to crime are learned and thus makes it difficult to operationalize the theory, except for looking at frequency, priority, duration, and intensity. With the aim of making Sutherland's nine principles on learning criminal behavior testable, Robert Burgess and Ronald Akers revised these principles by applying the concept of operant conditioning (Adams, 1973: p. 460). By revising Sutherland's basic assumptions they developed the notion of differential reinforcement which stresses the reinforcing effects of anticipated responses or punishments to criminal behavior.

In Akers' social learning version, individuals are neither natural-born deviants nor inherently social; they are simply neutral in learning behavioral models. The social context is thus an extremely important component in determining the behavior model that is chosen by the individual (Payne \& Salotti, 2007: p. 556). Behavior is strengthened when positive rewards are gained (positive reinforcement) and it is weakened when it is punished; and deviant behaviors are acquired in the same manner when a person's disorganized behaviors are reinforced, praised and encouraged by his role models.

Burgess and Akers' social learning model differs from the differential association theory in two aspects. Firstly, Burgess and Akers do not focus only on the primary groups as effective sources to acquire some sets of behaviors but also they point out that mass media, schools, and companies are also important socialization agents in the acquisition of these sets. Second, they suggest that positive consequences reinforce behavior by making it more likely to be repeated in similar situations (İçli, 2007: p. 120).

In a general sense, in explaining juvenile delinquency, learning theories focus person's parents and peer groups. There exist basically two groups of research which study juvenile delinquency in relation to familial relations and peer groups. Among the first group of these studies, juvenile delinquency is explored in accordance with the weak social control mechanisms, negligence and socio-demographic features of the family, fragmented family structure and poor parenting (Shavit \& Rattner, 1988; Sutherland \& Cressey, 1966; Glueck \& Glueck, 1974; Matsueda \& Heimer, 1987; McCord, 1991; Ireland \& Widom, 1994; Stouthamer-Loeber, Wei, Homish, \& Loeber, 2002). And the second group of studies simply focuses on deviant peer groups (Elliott, Huizinga, \& Ageton, 1985; Warr \& Stafford, 1991; Thornbery, Liozette, Krohn, Farnworth, \& Jang, 1994;
DeWit et al., 2000; Haynie, 2002; Chapple, 2005; Weerman \& Smeenk, 2005; Rebellon, 2006; Piquera et al., 2008).

Studying juvenile delinquency by taking parent or peer effects into consideration is an old trend in criminology (Ingram et al., 2007). Another important development in understanding peer influences on delinquency is the link between family relationships, mass communication and the peer influence (Marcos, Bahn, \& Johnson, 1986; Henry, Tolan, \& Gorman-Smith, 2001; Brendgen, Vitaro, Tremblay, \& Wanner, 2002; Ingram et al., 2007). This trend gives credit in social learning approaches because family relationships, violent or nonviolent delinquency of peers, involvement in deviant peer groups, and mass media as an impersonal agent to help socialization, and draws a big picture to explain juvenile delinquency. Some theoreticians suggest that the families, who are lack of effective discipline on and proper parental monitoring of the child's activities, increase the probability of the child's contact with deviant peers (Ingram et al., 2007)

Many studies have been made to test learning theories in the field of juvenile delinquency (Akers, Krohn, Lanza-Kaduce, \& Radosevich, 1979; Matsueda \& Heimer, 1987; Rebellon, 2006; Payne \& Salotti 2007). Brendgen et al. (2002) assert that personal traits, social-environmental factors like exposure to violence in media, chronic stress experienced in social networks, and problematic experiences with family and peer groups are effective altogether in juvenile's violent acts. It is also not surprising that during adolescence, varied types of associations with peers are both common and widespread (Warr, 2002). For example, by using data from the National Youth Survey, Warr (1993) found that peer relations (i.e., exposure to delinquent peers, time spent with peers, loyalty to peers) changed dramatically throughout adolescence, following much the same pattern as crime itself.

In the present study, the social cognitive model and the rejection sensitivity model are tested to assess the types of the mechanisms operate in the social environment which leads individuals into deviance. The social cognitive model focuses on the processes of imitation, reinforcement, and of observation in learning criminality from parents and peers; while according to the rejection sensitivity model ill-treatments or rejective manners of aggressive parents towards their children result in violence, which is also relevant for the case of peer groups, and for members who begin to act violently depending on their hostile and violent experiences in the group (Downey et al., 1996). The more a person receives hostile and violent attitudes in his family and peer groups, the more he tends to act violently and adopts this manner as habit, which results from the idea that he will always experience the similar hostility and violence in his family and peer networks.

The effects of social surrounding on juvenile delinquency are explored with four distinctive models by Henry et al. (2001). Moderate model regards families as having the ability to buffer the effects of deviant peer involvement. Buffering here implies a moderated relation in which the correlations between peer variables and individual variables differ among family types. A buffering model also suggests that in better functioning families, making contact with deviant peers does not produce the same effect as it does for youth in less well-functioning families, and thus risk is lower. Direct effects model implies that family and peer influences might operate as direct and parallel influences on delinquency. Such a direct relation would imply that family variables do not affect the selection of and the involvement in 
peer groups directly, but affect behavior by monitoring the adolescent's activities, through family relationships characteristics, and through patterns of family relationships and parenting characteristics. Fully mediated model is that deficient parenting practices might contribute to opportunities for deviant peer group involvement, which affect delinquency. Thus, the effects of families and of parenting would be mediated through involvement with deviant peers. Partially mediated model primarily concerns the mechanisms by which adolescents are rejected or accepted by either conventional or deviant peers. This model also suggests that families bring about coercive behaviors in children, which contribute to peer group selection and to delinquency. Thus, this model includes both direct and mediated effects of family relationships and parenting on delinquent behavior. In this model, deviant peers mediate the relation between parenting and individual violence. Parenting and family relationship characteristics promote association with deviant peers, which in turn increases the probability of delinquent behavior (Henry, Tolan, \& Gorman-Smith, 2001: p. 173). The results of the present study support the views argued by the partially mediated model.

The findings of Warr's (2005) study show that fathers that have stronger emotional bonds with their children are more likely to monitor and discipline their children and decrease their possibility of involvement in delinquent peer groups. Parallel to this research, in the research by Henry et al. (2001) it is shown that close family relations lower juvenile's probability of joining criminal groups and decreases the probability of commitment. There seen important links between family and friendship in the study of Wright et al. (2001) which examines family wealth. According to the family wealth approach, which forms the theoretical frame of the research, the families who invest their children with effort easily develop social ties with them. This kind of investment by the family is called family wealth. Family wealth is related to the lower level of friendships with criminal groups. The research of Ingram et al. (2008: p. 1) reveals that variables about family are indirectly related to the crime committed in later years but the friendship with criminals is directly and strongly related to criminality. Stouthamer and Louber (2002) found that the ill-treatment of the family has conserable effect on boys' heading for crime; whereas Sulivan's research (2006) shows that the effect of the family's behavior is less effective than that of the friend groups.

Another model on juvenile delinquency, which relates criminality to self-esteem, explains criminality in relation to individual self-esteem. According to Gottfredson and Hirschi, individuals with lower self esteem are reactive and insensitive, behave according to the physical triggers, and they are narrow minded and have low frustration tolerance; as they have these characteristics they are more inclined to committing crimes (Gottfredson \& Hirschi, 1990). Low self-confidence leads to being socially unsuccessful. Unemployment, friendships with wrapped groups and behaviors like wasting time at streets are evaluated as the primary results of the factors that lead to criminal acts (Baron, 2003: p. 403).

The other explanation to the juvenile delinquency is General Strain Theory developed by Agnew. According to Agnew, negative factors such as the failure in achieving goals which are valued positively (unemployment), and the existence of harmful stimulants (homelessness) make a pressure on the individual, which causes crime (Baron, 2003: p. 407). In his study, Baron (2003) explains these unfavorable relationships in relation to low selfconfidence. The young with low self-confidence join to deviant peer groups; they embrace deviant values like unemployment and homelessness. As a result they tend to commit crime.

Another study on General Strain Theory was made by Ostrowsky and Messner (2005). In this study, the validity of the theory is evaluated and the General Strain Theory is surveyed under three titles; life struggle, victimization strain and neighborhood strain. Each of these variables is investigated on the basis that the ways they affect the opportunities in young adults' lives with regards to the appreciated and unappreciated goals. As a result, the General Strain Theory is supported with the findings concerning that these variables prepare inhibitive living conditions to these young adults and hereby they tend to commit crime.

\section{Method}

1526 juveniles, who are reported as crime suspects in the city centers and districts of Ankara and Istanbul; are selected through cluster sampling with the significance level of $95 \%$.

Preparatory to the research, pollsters comprised of sociologists and psychologists are trained on conducting a questionnaire and making an interview. The number of juveniles, who are reported by virtue of criminal charge to the bureaus in the city center and central districts of Ankara and Istanbul, were 18.272 in 2004.

In order to strengthen the representation of the sample, the number of subjects was increased to 770 in each city to make the number of the sample groups equal. Children Branch Offices in Istanbul (Kadıköy, Sarıyer, Beşiktaş, Beyoğlu, Bayrampaşa) and Ankara; Social Work and Children Protection Establishment's and some other private foundations' dormitories (as Yel Değirmeni Children Center, Istanbul Bahçelievler 80.Year Girl Dormitory, Istanbul Florya Youth Center, Istanbul Ağaçlı Children Dormitory, Umut Foundation), Istanbul Municipality Job Acquirement Center (ISMEM), and Crime and Arrestment foundations in Ankara and Istanbul where accommodate female and male prisoners and convicts under the age of eighteen (Elmadağ, Paşa Kapısı and Bayrampaşa) were visited.

In addition to questionnaire application, deep interviews were employed with the juveniles who were brought to youth offices by virtue of criminal charge.

In an effort to find out the demographic, socio-cultural and economic characteristics of the families and of the juveniles included in the sample, and to figure out by which reasons and what kind of crimes, the juveniles are exposed to or commit; an open-ended and multiple choice questionnaire of 188 questions was applied to juveniles, and interviews were made with some of them.

Firstly the sample group is described through one-dimension tables that are shaped according to the data obtained by means of questionnaires. The correlation between the result variables and the variables considered to be effective, were investigated through cross tabulation and multivariate analysis, with the aim of determining the crime types the juveniles committed and the reasons of taking part in those crimes, after running away from home, beginning to live and work in streets, and exposing to crime. By applying the techniques of 1) Homogeneity and 2) three-dimensional tables throughout the multivariate analysis, possible correlations among variables were tested.

Hypotheses, developed for the present research are mentio- 
ned below:

1) There is a positive correlation between the mother's educational level and the type of the crime juvenile commits.

2) There is a positive correlation between the father's educational level and the type of crime juvenile commits.

3) There is a positive correlation between the amount of the time the child spends on streets and his involvement into criminal acts.

4) There is a positive correlation between juvenile's crimes and the type of peers' crimes.

\section{Results}

$50.6 \%$ of the research sample is constituted of juveniles live in Ankara; and $49.4 \%$ live in Istanbul. In the analysis of the juvenile's birthplaces; it is seen that the biggest proportion $(36.6 \%)$ is composed of the juveniles from Central Anatolia Region. Besides, it is found out that $22.2 \%$ of the sample was born in cities in Marmara Region, $12.4 \%$ of them was born in cities in Southeastern Anatolia Region.

$66.3 \%$ of the children to whom the questionnaires were applied, and with whom the interviews made in Ankara and Istanbul are between the ages of $16 \%$ and $19 \%$, and $27.9 \%$ are between the ages of $12-15$. The majority of the juveniles in the sample group are between the ages of $12-19$.

Approximately $88 \%$ of the juveniles are male and $12 \%$ of them are female.

During the research $80.5 \%$ of the sample stated that their families live in the town center.

When the educational level of the sample were examined it was found that $15.5 \%$ of them are literate, $12.7 \%$ are elementary school (primary and secondary school) students, $40.5 \%$ are elementary school graduates, $18.2 \%$ are high school students, and $3.5 \%$ of them are high school graduates.

$81.5 \%$ of the juveniles mentioned that they wish for a higher level of education. Some of the juveniles declared that they had never attended to school for various reasons. While the first of these reasons is the juvenile's own unwillingness $(30.5 \%)$; the second reason is the disallowance of the families $(27.7 \%)$, and the last reason is related with the family's poverty $(26.2 \%)$.

$92.5 \%$ of the sample stated that their mothers are alive; $87.1 \%$ of them stated that their fathers are alive. Moreover $70.8 \%$ of them denoted that their parents live together.

$30.1 \%$ of the juveniles' mothers are illiterate, whilst $29.1 \%$ are primary school graduates. While the rate of mothers who are only literate is $16.7 \%$; the rate of mothers that have high school or bachelor's degree is considerably low $(7.0 \%$ and $1.5 \%$ ). $7.5 \%$ of juveniles' fathers are not literate and $33.8 \%$ of fathers are primary school graduates. The rate of fathers who are merely literate is $13.1 \%$; the rate of fathers who have high school degree is $10.3 \%$, and the rate of university graduate fathers is only $3.3 \%$.

In the examination of the fathers' occupational status; it has been found out that $60.5 \%$ of the fathers have a regular job. In parallel with the educational level, only $13.4 \%$ of mothers have regular jobs and $78.4 \%$ of them are housewives.

While $25.5 \%$ of the sample live in big families consisting of 7 or more members; $22 \%$ of the juveniles live in families with 4 members. $54.2 \%$ of the sample usually live with their parents and siblings. It can be hereby concluded that one third of the juveniles live in large families (with 7 or more members).

$38 \%$ of the sample are found to be migrated from another city to Ankara or Istanbul; among these families while $46.8 \%$ are from East (23.5\%) and Southeastern Anatolia (23.3\%), $13.7 \%$ are from Central Anatolia. More than half of the families $(55.6 \%)$ migrated for the purpose of finding a better job.

In a comparison of the number of siblings; it is found that $3.1 \%$ of the sample are singletons. While juveniles with 1 to 3 siblings are uppermost of this comparison (54.5\%), juveniles with 4 to 6 siblings $(27.5 \%)$ take the second place and juveniles with 7 or more siblings $(14.6 \%)$ come third.

When the juveniles were asked the person that maintains the family; $28.6 \%$ of them reported that it is their fathers who maintains the family, $10.9 \%$ reported that their sibling/s maintain(s) the family, $3.2 \%$ reported that the person who brings up the family is the mother, $2.6 \%$ reported they are assigned for this responsibility, and $51.4 \%$ reported all the family members work in a job to earn a living for their family.

During the course of the research, $42.2 \%$ of the sample was living at home, $35 \%$ of the sample in prison, and $19.5 \%$ in an institution.

In the course of the research, it's discovered that $39 \%$ of the sample had been staying in their current place for two and a half years or more, $27.1 \%$ had been living in their current place for $1-3$ months and $11.9 \%$ had been living at the same place for $4-6$ months.

$67.7 \%$ of the sample was not working during the time of the research. In relation to this fact, the sample was asked whether he/she had ever worked before or not. According to the answers; the majority of the sample $(81.9 \%)$ had been working to earn money until the research time. While $36.7 \%$ of the sample started working between the ages of $12-14 ; 25.2 \%$ started working between the ages of $9-11.68 .8 \%$ of the juveniles worked at a workplace and $18.4 \%$ worked on streets. In addition to these findings, it is proper to state that $36 \%$ of the juveniles working at a work-place was an apprentice in a store, and while $69 \%$ of juvenile stated that working at a job was their own choice; $67.2 \%$ of them mentioned that their families allowed them to find a job and work.

As another interesting finding, it is important to note that more than half of the sample (52\%) had spent the whole night outside for one or more times. And when the reasons of staying outside during the nighttime are asked to the sample, $39 \%$ explained that they were not willing to go home; and $32.7 \%$ stated that he/she enjoyed the idea of staying outside.

$74.6 \%$ of the sample had not been punished for any crime before. $60.9 \%$ of the juveniles, who had committed crime, had been imprisoned before. $61.4 \%$ of the sample who were either arrested or sentenced are between the ages of $5-17$. While the first crime of $15.4 \%$ of the juveniles was murder, laceration or beating, it was theft, swindling, pick pocketing and purse-snatching for $37.2 \%$ of them, and $9.4 \%$ of them committed various kinds of theft. $70.9 \%$ of the sample committed their first crime on the streets; and $27.4 \%$ of them committed for the first time for money. And similarly $67.4 \%$ of the sample committed their last crime on the streets and $24.2 \%$ of them did it for money.

Another crucial finding to note is that social surroundings, friends and the television are the negative (role) models for $39.7 \%$ of the juveniles to get the idea of committing crime. While $37.9 \%$ of the juveniles were aided and abetted in committing crime, $71.2 \%$ of the juveniles stated that the people who aided and abetted them were their friends.

Another crucial finding to note is that social surroundings, friends and the television are the negative (role) models for 
$39.7 \%$ of the juveniles to get the idea of committing crime. While $37.9 \%$ of the juveniles were aided and abetted in committing crime, $71.2 \%$ of the juveniles stated that the people who aided and abetted them were their friends.

Despite $87 \%$ of the juveniles' families were trying to prevent their children from committing crime, $95.8 \%$ of the sample mentioned that he/she had criminal friends, and $84.5 \%$ of them described those friends as the close ones. More than half of the juveniles (63.7\%) spent their spare times with their friends and $86.4 \%$ of them reported to had been getting on well with their friends. The rate of juveniles' friends living or working on streets is $36.8 \%$; and $47.7 \%$ of the sample group had friends who were arrested or imprisoned before.

When the crimes committed by the friends of the sample are examined, it is seen that with the rate of $21 \%$ theft, swindling, pick pocketing and purse snatching are crimes committed most. Moreover while the second greatest crime types are found as murder, laceration and beating (14.4\%) among the friends; the third greatest crime types are found to be as damaging people's belongings in the manner of theft $(11.9 \%)$.

$50.9 \%$ of the sample were away from home for one and half year or more and $21.5 \%$ of them were for one to three months. $39.8 \%$ of the juveniles was between the ages of 15 to 17 when they first left home, $25.5 \%$ were between the ages of $12-14$, and $15.6 \%$ were between the ages of $9-11$. Having familial problems is the basic reason for almost the entire sample to leave home. For $10.5 \%$ of the juveniles, being exposed to domestic violence by their parents is the basic reason for leaving the home for the first time.

$77.3 \%$ of the sample usually ran away from home and $47.6 \%$ of them had been ran away from home for five times or more, and $35.1 \%$ of them had been ran away from home for one or two times. While more than half (53.2\%) of those who ran away from home, accused their families for causing that; $21.5 \%$ of them addressed their friends.

$45.6 \%$ of the sample stated that they ran away from home for the first time when they were at the ages of $13-16$, and $35.6 \%$ of them when they were at the ages of $9-12.35 .8 \%$ of the sample mentioned that they had ever stayed away their home for 18 or more days, and $25.8 \%$ of them had stayed outside for 2 - 5 days.

$91.3 \%$ of the juveniles returned home and when a comparison is made among them, it is seen that while $51.1 \%$ of the group returned home willingly, $29.1 \%$ of them returned home with their families' enforcement.

\section{Discussion}

This study basically portrays a serious table of facts. First of all, juveniles start committing severe violent crimes as theft, swindling, pick pocketing, purse-snatching and murder, laceration, and beating mostly between the ages of $15-17$. This portray reveals various outcomes about the juvenile's relations with the family and with friends as the considerable reason of delinquency.

The education level of juveniles' families are low and almost the half of their families (43.9\%) migrated from East and South East Anatolia with the aim of finding job. Most of the families have been living in the same place for more than ten years, and the rate of the juveniles whose fathers have regular jobs is $60 \%$.

The cross table analysis shows a low correlation between the mother's educational level and the type of crime the juvenile commits. While the juveniles of illiterate mothers commit purse snatching and narcotic crimes more than expected; the ones of mothers who continued but did not get primary school graduation, commit the crimes of murder and laceration, and the juveniles' whose mothers are primary school graduates committed crimes as theft and causing damage to property, less than expected. These outcomes reinforce the first hypothesis weakly. Any remarkable data is found out to show that an increase at the mother's educational level influences the juvenile's criminality negatively. This outcome can be explained by the insufficient number of juveniles who have high school or university graduate mothers.

Besides, there found a significant correlation between the father's educational level and the crime types committed by the juveniles $\left(\mathrm{X}^{2}=107.2 ; \mathrm{P}=0.023\right)$. The juveniles of fathers that are high school graduates commit some crime types less than expected. Parallel to this, while the juveniles of university graduate fathers, commit crimes like theft/swindling/pick pocketing/purse-snatching less than expected; the ones of middle school graduate fathers commit crimes such as swearing and insulting public officers more than expected. Therefore it can be concluded that the second hypothesis is verified. There is a negative correlation between the father's educational level and the violent crimes committed by the juvenile. When considering the fact that juveniles commit crime are mostly male $(87.5 \%)$, it can be seen that the father is a more effective role model than the mother in terms of the educational level and life style; and the father of these characteristics shapes the criminal life of the juvenile indirectly.

When the education level of juveniles is checked over, it is seen that most of them are at the level of secondary education. On the other hand $81.9 \%$ of the juveniles are observed to have started working as an apprentice in a store or selling tissue, pencil etc. on the streets at very early ages and mostly before the age of 18. It is important to note that the families of these juveniles approve and encourage them to work; therefore working on the streets is, correspondingly, an indirect obstacle against going to school and receiving education. Even though the juveniles are supposedly having official education, they are forced to give up their education and to work, by their parents through time. It is a common fact for the juveniles of poor families moving from underdeveloped regions to big cities in Turkey, to start working at early ages. This fact makes surviving in big cities easier for the poor families when their children start working as early as possible. Some of them either take safe jobs as apprenticeship or tinker, but some others work under extremely risky conditions like selling handkerchiefs, adhesive plaster, and flowers on the streets or waiting near the traffic lights to clean car windows. As pointed out before, the juveniles deprived of any profession or high education, have to face various risky factors in their work places.

The reason why juveniles among the sample never got any formal education can be explained firstly with their unwillingness $(30.5 \%)$. While the families' disallowance $(27.7 \%)$ can be shown as the second reason; the third common reason of this fact is financial difficulties $(26.2 \%)$. The juveniles, who are able to have formal education, do also work in a job to earn money as soon as possible since they aim to be economically independent of their families; therefore as those juveniles attribute more importance to working than going school, after a while they leave school and begin to work in various jobs.

One of the findings of great importance can be shown as the 
fact that the majority of the juveniles ran away from home before the age of 18 , and the quarrels within the family play a negative effect on this situation. Moreover, the juveniles are considered to spend most of their time with their friends after leaving home.

In reference to the third hypothesis asserting the idea that the longer the juvenile lives on street the more frequently he will commit crime, the probability of committing crime for the ones who live on streets for $10-12$ months length, is found to be 3,46 times higher than expected $(z=3.9)$. It is observed that the probability of committing crime is not significantly high for the juveniles having lived less or more than this period of time. Accordingly, the third hypothesis supporting the idea that 'there is a relation between the time period spent outside and the rates of crimes committed' is not supported.

While the rate of juveniles who live together with their friends during the time of research is $38.3 \%$, the juveniles living together with their family follow this rank with the ratio of $38 \%$. Living together with friends makes learning to commit crime easier, and it has to be stated that although these juveniles have severe arguments with their families and run away from home, they emphasized that they never completely break away from their families.

It is relevant to stress that in case the juveniles stay away from home, the probability of being exposed to and of learning criminal acts considerably increases. As they spend most of their time on the streets, it has been understood that they started committing crimes or still committing them again on the streets, and generally for money. It is seen that their current crimes and earlier crimes are similar to each other and money is the main reason for committing those crimes.

The rate of the juvenilees commit crime within the circle of friends is high. Another striking point is that their friends were also arrested for similar crimes like murder/laceration/beating and theft, swindling/pick pocketing/purse-snatching. It is also seen that the juveniles learn the notion of committing crime from their friends and they are supported and encouraged pretty much by their friends in committing crime. More than half of the juveniles $(63.7 \%)$ spent the majority of their time with their friends, $36.8 \%$ of them have friends who work or live on the streets. Moreover, approximately half of the group has friends who were arrested or imprisoned because of a criminal act committed before. These findings indicate the source of the idea of committing crime as the circle of friends. Another finding about the effect of friendship on crimes is the similarity between the crimes committed by the juveniles and his friends. A strong relation is observed between the types of crimes which caused the juveniles to be arrested and the type of crime committed by his peer groups. In other words, it is more likely for them to commit theft when their friends do it so and to commit crimes as abuse/sodomy like their friends (Chi-Square $=1037,430$; $\mathrm{P}=0,000)$. There are considerable similarities in the cross table analysis under the following headings: The frequency of murder is 7 times higher if the juvenile has a friend who committed murder $(z=5.9)$; the frequency of committing theft is 2 times higher than expected in case of having a friend who committed theft, and the frequency to commit crime is 3 times higher than expected if the child has a friend who was arrested because of laceration $(\mathrm{z}=3.5)$. More strikingly, the probability of committing abuse or sodomy is 20 times higher than expected if the juvenile's friend groups commits these crimes $(z=10.2)$. And similarly the frequency of committing various kinds of theft is also 40 times higher than expected for the ones who have friends with various kinds of theft $(z=11.2)$. Therefore it is proper to mention that these data support hypothesis 4 .

It is seen that families try to keep their children away from crime and they definitely do not approve of their crimes. Besides, by encouraging the children to work in early ages the families prevent them from completing their education and developing organized life styles. When the quarrels between the juvenile and the family, and the economic problems are considered with this case, it is found that the juvenile is more likely to run away from home in early ages. As a consequence of this fact, even though the family does not directly encourage the juvenile to commit crime, they lose their social control on their children at a great extend, especially during this period. As the time spent on the streets increases the juvenile becomes a member of a new criminal social network. By developing differential associations with their friends, the juveniles turn into crime mostly because of economic concerns. The violence within the crimes of these juveniles also shows the lack of social control on them.

The data of this research on juvenile delinquency in relation to family and peer networks briefly reveal these points: The family has an indirect and partial effect on juvenile's tendency to commit crime because they cannot provide organized social networks, role models, and social controls for their children. For this reason it can be concluded that the families have a secondary influence on juvenile delinquency. On the other hand, by developing a differential association with the juvenile, by which violence and criminal acts are learned, legitimated, supported or encouraged; the peer network has a direct and an incredible influence to initiate the juvenile into crime.

\section{REFERENCES}

Adams, R. (1973). Differential association and learning principles revisited. Social Problems, 20, 458-470. doi:10.1525/sp.1973.20.4.03a00060

Akers, R. L., Krohn, M. D., Lanza-Kaduce, L., \& Radosevich, M. (1979). Social learning and deviant behavior: A specific test of a general theory. American Sociological Review, 44, 635-655. doi: $10.2307 / 2094592$

Bandura, A. (1977). Social learning theory. New York: General Learning Press.

Baron, S. W. (2003). Self-control, social consequences and criminal behavior: Street youth and the general theory of crime. Journal of Research in Crime and Delinquency, 40, 403-425. doi: $10.1177 / 0022427803256071$

Brendgen, M., Vitaro, F., Tremblay, R. E., \& Wanner, B. (2002). Parent and peer effects on delinquency related violence and dating violence: A test of two mediational models. Social Development, 11, 225-244. doi:10.1111/1467-9507.00196

Burgess, R. L., \& Akers, R. L. (1966). A differential association-reinforcement theory of criminal behavior. Social Problems, 14, 128-147. doi:10.1525/sp.1966.14.2.03a00020

Chapple, C. L. (2005). Self-control, peer relations and delinquency. Justice Quarterly, 22, 89-106. doi:10.1080/0741882042000333654

Cullen, F. T., \& Agnew, R. (2003). Criminological theory: Past to present. Los Angeles, CA: Roxberry Publishing Company.

DeWit, D. J., Offord, D. R., Sanford, M., Rye, B. J., Shain, M., \& Wright, R. (2000). The effect of school culture on adolescent behavioral problems: Self-esteem, attachment to learning and peer approval of deviance as mediating mechanisms. Canadian Journal of Social Psychology, 16, 15-38.

Downey, G., \& Feldman, S. I. (1996). Implications of rejection sensitivity for intimate relationships. Journal of Personality and Social Psychology, 70, 1327-1343. doi:10.1037/0022-3514.70.6.1327 


\section{T. G. İÇLI ET AL}

Elliott, D., Huizinga, D., \& Ageton, S. (1985). Explaining delinquency and drug use. Beverly Hills, CA: Sage.

Glueck, S., \& Glueck, E. (1974). Delinquency and crime. Springfield: Charles C. Thomas Pub.

Gottfredson, M., \& Hirshi, T. (1990). A general theory of crime. Stanford, CA: Stanford University Press.

Haynie, D. L. (2002). Friendship networks and delinquency: a relative nature of peer delinquency, Journal of Quantitative Criminology, 18, 99-134. doi:10.1023/A:1015227414929

Henry, D. B., Tolan P. H., \& Gorman-Smith, D. (2001). Longitudinal family and peer group effects on violence and delinquent behavior. Journal of Clinical Child Psychology, 30, 172-186.

Ingram, J. R., Patchin, J. W., Huebner, B. M., McCluskey, J. D., \& Bynum, T. S. (2007). Parents, friends and serious delinquency: An examination of direct and indirect effects among at-risk early adolescents. Criminal Justice Review, 32, 380-400. doi:10.1177/0734016807311436

İçli, T. (2007). Kriminoloji. Ankara: Seçkin Yayınları.

Marcos, A., Bahr, S., \& Johnson, R. (1986). Test of bonding/association theory of adolescent drug use. Social Forces, 65, 135-160.

Matsueda, R. L., \& Heimer, K. (1987). Race, family structure and delinquency: A test of differential association and social control theories. American Sociological Review, 52, 826-840. doi: $10.2307 / 2095837$

McCord, J. (1991). Family relationship, juvenile delinquency and adult criminality. Criminology, 29, 397-417. doi:10.1111/j.1745-9125.1991.tb01072.x

Ormrod, J. E. (1999). Human learning. Upper Saddle River, NJ: Prentice-Hall.

Ostrowsky, M. K., \& Messner, S. F. (2005). Explaining crime for a young adult population: An application of general strain theory. Journal of Criminal Justice, 33, 463-467. doi:10.1016/j.jcrimjus.2005.06.004

Payne, A. A., \& Salotti, S. (2007). A comperative analysis of social learning and social control theories in the prediction of college crime.
Deviant Behavior, 28, 553-573. doi:10.1080/01639620701357933

Piquero, N. L., Gover, A. R., MazDonald, J. M., \& Piquero, A. (2005). The influence of delinquent pers on delinquency: Does gender matter? Youth and Society, 36, 251-275. doi:10.1177/0044118X04265652

Rebellon, C. J. (2006). Do adolescents engage in delinquency to attract the social attention of pers? An extension and longitudinal test of the social reinforcement hypotesis. Journal of Research in Crime and Delinquency, 43, 387-411. doi:10.1177/0022427806291259

Shavitt, Y., \& Rattner A. (1988). Age, crime and early life course. American Journal of Sociology, 53, 81-93.

Stouthamer-Loeber, M., Wei, E. H., Homish, D. L., \& Loeber, R. (2002). Which family and demographic factors are related to both maltreatment and persistent serious juvenile delinquency? Children's Services: Social Policy, Research and Practice, 5, 261-272. doi:10.1207/S15326918CS0504_3

Sullivan, C. J. (2006). Early adolescent delinquency: Assessing the role of childhood problems, family environment and peer pressure. Youth Violence and Juvenile Justice, 4, 291-313. doi: $10.1177 / 1541204006292656$

Sutherland, E., \& Cressey, D. (1966). The principles of criminology. Philadelphia: Lippincott Comp.

Thornberry, T., Lizotte, A., Krohn, M., Farnworth, M., \& Jang, S. (1994). Delinquent peers, beliefs, and delinquent behavior: A longitudinal test of interactional theory. Criminology, 32, 47-83. doi:10.1111/j.1745-9125.1994.tb01146.x

Warr, M., \& Stafford, M. (1991). The influence of delinquent peers: What they think or what they do? Criminology, 29, 851-865. doi:10.1111/j.1745-9125.1991.tb01090.x

Weerman F. M., \& Smeenk, H. W. (2005). Peer similarity in delinquency for different types of friends: A comparison using two measurement method. Criminology, 43, 499-524. doi:10.1111/j.0011-1348.2005.00015.x

Wright, J., \& Cullen, F. (2001). Parental efficacy and delinquent behavior: Do control and support matter? Criminology, 39, 677-705. doi:10.1111/j.1745-9125.2001.tb00937.x 